SECTION 31. Economic research, finance, innovation

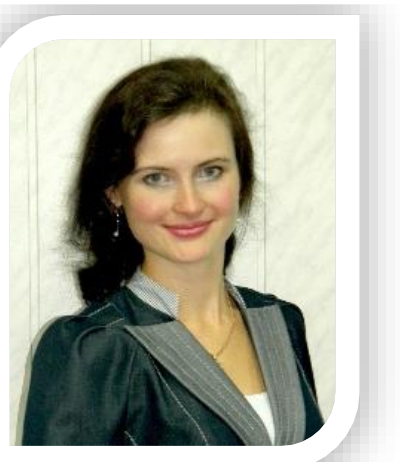

Bondarevska Kseniia Valentinovna

$\mathrm{PhD}$ in Economics, Associate Professor of Department of Personnel Management and Labour Economics

Dnepropetrovsk State Financial Academy

Kseny-8888@mail.ru

\title{
MATERIAL AND TECHNICAL PROVIDING OF AGRARIAN ENTERPRISES AS A FACTOR OF ITS PROFITABILITY
}

Abstract: The problem questions of material and technical providing of agricultural enterprises in the context of increase of its profitability and competitiveness are certain in the article. The key directions of state policy in sphere of technical and technological retooling of agrarian enterprises and it further development in the context of globalization trends are grounded.

Key words: material and technical providing, agrarian sector, technical retooling, innovation, state regulation.

\section{УДК 338.43.01/02.075.8}

\section{МАТЕРИАЛЬНО-ТЕХНИЧЕСКОЕ ОБЕСПЕЧЕНИЕ АГРАРНЫХ ПРЕДПРИЯТИЙ КАК ФАКТОР ИХ ПРИБЫЛЬНОСТИ}

Аннотация: В статье определены проблемные вопросы материальнотехнического обеспечения сельскохозяйственных предприятий в контексте роста их прибыльности и конкурентоспособности. Обоснованы ключевые направления государственной политики в отрасли технико-технологического переоснащения предприятий АПК и их дальнейшего развития в условиях глобализационных тендениий.

Ключевые слова: Материально-техническое обеспечение, аграрный сектор, техническое переоснащение, инновации, государственное регулирование.

Развитие аграрного сектора экономики в современных условиях характеризуется необходимостью решения проблемних вопросов, среди которых обеспечение прибыльности и конкурентоспособности сельскохозяйственной продукции. Так, в 2012 году общий уровень рентабельности производства по Украине составил 20,5 \% (для сравнения: рентабельность в 1990 году составляла 42,6\%). К сожалению, динамика прибыльности аграрных предприятий в последние годы имеет тенденцию к уменьшению. Низкой остается рентабельность основных видов продукции животноводства. В условиях развития глобализационных процессов возникает необходимость наращивания объемов производства и качества производимой продукции, что будет способствовать повышению конкурентоспособности предприятий отрасли. Одним их ключевых элементов увеличения аграрного потенциала страны является материально-техническое обеспечение сельскохозяйственных предприятий.

Технико-технологическое переоснащение каждого предприятия сельского хозяйства в целом является основным направлением повышения эффективности использования трудовых, земельных ресурсов, комплексной механизации и автоматизации технологических процессов, интенсификации производства и на этой основе повышения урожайности сельскохозяйственных культур, продуктивности скота, объемов и качества продукции, рентабельности и прибыльности производства [1, с. 
240]. Таким образом, положительное влияние на прибыльность, а затем и на конкурентоспособность предприятий отрасли может осуществить обновление материально-технической базы, что будет способствовать росту объемов производства и улучшению основных экономических показателей. Сейчас уровень обеспечения сельскохозяйственных предприятий тракторами, комбайнами и другой техникой составляет $45-50 \%$ от потребности, при этом более $85 \%$ технических средств требуют немедленной замены вследствие их сношенности [6, с. 181].

Уменьшение объемов производства средств механизации для сельского хозяйства и рост цен на них при отсутствии финансов у сельскохозяйственных предприятий приводит к увеличению сроков эксплуатации техники, что отрицательно сказывается на ее технических характеристиках, приводит к нарушению терминов выполнения сельскохозяйственных работ [7].

Из-за физического износа сельскохозяйственной техники возрастают расходы топливно-смазочных материалов в расчете на единицу работ. Все это, в свою очередь, приводит к росту нагрузки на технику, значительным потерям урожая и повышению себестоимости. Объем материально-технического обеспечения сельскохозяйственных предприятий Украины имеет тенденцию к уменьшению (табл. 1).

Таблица 1

Наличие основных видов сельскохозяйственной техники на предприятиях отрасли*

\begin{tabular}{|c|c|c|c|c|c|c|c|}
\hline \multirow[b]{2}{*}{ Виды техники } & \multirow[b]{2}{*}{1991} & \multirow[b]{2}{*}{2000} & \multirow[b]{2}{*}{2009} & \multirow[b]{2}{*}{2010} & \multirow[b]{2}{*}{2011} & \multicolumn{2}{|c|}{2012} \\
\hline & & & & & & всего & $\begin{aligned} \text { в \% к } \\
1991 \text { г. }\end{aligned}$ \\
\hline Тракторы, тыс. шт. & 497,3 & 318,9 & 168,5 & 151,3 & 147,1 & 150,1 & 30,2 \\
\hline на 1000 га пашни, шт. & 14 & 11 & 9 & 8 & 8 & 8 & 57,1 \\
\hline $\begin{array}{l}\text { Зерноуборочные } \\
\text { комбайны, тыс. шт. }\end{array}$ & 105,2 & 65,2 & 36,8 & 32,8 & 32,1 & 32 & 30,4 \\
\hline $\begin{array}{llll}\text { на } & 1000 \text { га } & \text { посевной } \\
\text { площади, шт. } & \\
\end{array}$ & 8 & 6 & 3 & 4 & 4 & 4 & 50,0 \\
\hline $\begin{array}{l}\text { Кукурузоуборочные } \\
\text { комбайны, тыс. шт. }\end{array}$ & 15,3 & 7,9 & 2,9 & 2,5 & 2,3 & 2,1 & 13,7 \\
\hline $\begin{array}{l}\text { на } 1000 \text { га } \\
\text { площади, шт. }\end{array}$ & 12 & 8 & 2 & 1 & 1 & 1 & 8,3 \\
\hline $\begin{array}{ll}\text { Доильные } \quad \text { установки } \\
\text { агрегаты, тыс. шт. }\end{array}$ & 79,2 & 33,5 & 10,5 & 10,9 & 10,8 & 11,2 & 14,1 \\
\hline
\end{tabular}

* рассчитано автором согласно данных [10]

Следовательно, ниличие тракторов и зерноуборочных комбайнов в 2012 году составило только 30,2 \% и 30,4 \% соответственно от аналогичного показателя 1991 года. Сельскохозяйственной техникой в расчете на 1000 га посевной площади отечественные предприятия обеспечены только наполовину. Несколько хуже ситуация в сфере обеспеченности кукурузоуборочными комбайнами и доильными установками (только 13,7\% и 14,1 \% от 1990 года соответственно). В современных условиях возникает необходимость в реформировании системы государственного регулирования АПК, в частности в разрезе материально-технического переоснащения предприятий и внедрения инноваций.

В целом система материально-технического обеспечения представляет собой совокупность предприятий-производителей материально-технических ресурсов, торгово-посреднических организаций, государственных органов, которые регулируют отношения в сфере технико-технологического обеспечения [8]. С целью обеспечения развития и финансирования системы материально-технического обеспечения внедряются соответствующие государственные программы. В частности, на реализацию Программы технического переоснащения сельскохозяйственных формирований Днепропетровской области (Украина) было выделено 224,3 млн. грн. 
(28,06 млн.\$), в том числе 115,3 млн.грн. (14,43 млн.\$) собственных средств сельскохозяйственных предприятий, 105 млн. грн. (13,14 млн.\$) - банковских кредитов и 12 млн. грн. (1,50 млн.\$) - средств областного бюджета. Кроме того, средства бюджета области направляются на удешевление затрат на приобретение тракторов государственного предприятия «ВО «Южный машиностроительный завод им. А.М. Макарова» [9].

Программа технического переоснащения аграрных предприятий несколько активизировала обновление тракторного парка и способствовала улучшению уровня его использования. Тем не менее, следует отметить целесообразность направленности государственной политики на высокотехнологическое развитие аграрных предприятий, что станет возможным благодаря обеспечению инвестиционных поступлений. Финансирование инновационного развития сельскохозяйственных предприятий несколько тормозится из-за реформирования отношений собственности и создания частных структур. В особенной защите со стороны государства нуждаются небольшие сельскохозяйственные предприятия, которые не могут самостоятельно выйти из кризисной ситуации или находятся на грани банкротства. Также отрасль сельского хозяйства требует дополнительного финансового обеспечения из-за особенностей производства, среди которых: сезонность и следствия действия природноклиматических условий, необходимость полного обеспечения посевным материалом, минеральными удобрениями и средствами защиты растений, повышения плодородия почв. Положительный эффект в контексте повышения прибыльности сельскохозяйственных предприятий будут иметь интеграционные процессы в сфере АПК, в частности создание крупных агропромышленных комплексов с ориентацией на их инновационное развитие. Кроме того, с целью улучшения состояния формирования материально-технической базы важным является осуществление активной государственной поддержки отечественных товаропроизводителей при помощи бюджетных, налоговых, ценовых и кредитных инструментов.

\section{Литература}

1. Биляк Н.И. Оценка современного состояния материально-технического обеспечения АПК // Сб. науч. тр. ЛНАУ. 2004. №34/46. 384 с.

2. Билоусько Я.К., Товстопят В.Л. Государственная поддержка технико-технологического переоснащения аграрного производства. К.: ННЦ ИАЭ. 2008. 56с.

3. Бондаревская К.В. Эффективность использования персонала аграрных предприятий : монография. Днепропетровск: Днепроп. гос. фин. акад. 2013. 164 с.

4. Бондаревская К.В. Особенности реализации государственной региональной политики в отрасли сельского хозяйства // Вестник Запорожского национального университета: Сборник научных трудов. Экономические науки. Запорожье: Запорожский национальный университет. 2012. С.107-112.

5. Клименчукова Н.С. Научно-теоретические основы организации управления материальнотехническим обеспечением сельскохозяйственных предприятий. URL: http://www.kbuapa.kharkov.ua/e-book/db/2012-2/doc/2/16.pdf (дата обращения 30.01.2013)

6. Немченко В.В. Продовольственная безопасность Украины // Сборник научных трудов ВНАУ. Серия: Экономические науки. №4 (70). Том 2. 2012. С.179-183.

7. Организация производственного обслуживания сельскохозяйственных предприятий. URL: http://agroua.net/economics/documents/category-121/doc-157/ (дата обращения 30.01.2013)

8. Остапенко Т. М. Формирование материально-технического обеспечения сельскохозяйственных предприятий : автореф. дис. канд. экон. наук / Т. М. Остапенко. Луганск: ЛНАУ. 2008. 20 с.

9. Решение Областной Рады Про Программу технического переоснащения сельскохозяйственных формирований Днепропетровской области в 2010 - 2012 годах. URL: http://oblrada.dp.ua/official-records/decisions/0/449 (дата обращения 20.01.2013)

10. Сельское хозяйство Украины за 2012 год: Статистический сборник. К.: Государственная служба статистики Украины. 2013. 402 с. 